Volume 5 Number 1 April 2019 page 39-48

p-ISSN:2460-1497 and e-ISSN: 2477-3840

DOI: https://doi.org/10.26858/est.v5i1.8231

\title{
Identification Attitudes of Learners on Physics Subjects
}

\author{
Astalini $^{1}$, Dwi Agus Kurniawan ${ }^{2}$, Rahmat Perdana ${ }^{3}$, Wawan Kurniawan ${ }^{4}$ \\ ${ }^{1}$ Physics Education, Universitas Jambi, Indonesia \\ Email: astalinizakir@unja.ac.id \\ ${ }^{2}$ Physics Education, Universitas Jambi, Indonesia \\ Email: dwiagus.k@unja.ac.id \\ ${ }^{3}$ Physics Education, Universitas Jambi, Indonesia \\ Email: rahmat260997@gmail.com \\ ${ }^{4}$ Physics Education, Universitas Jambi, Indonesia \\ Email: kurniawan_wawan@unja.ac.id
}

(Received: February-2019; Reviewed: February-2019; Accepted: March-2019; Published: April-2019)

(i) () (92019 - EST Graduate Program Universitas Negeri Makassar. This is an article with open access under license CC BY-NC-4.0 (https://creativecommons.org/licenses/by-nc/4.0/).

\begin{abstract}
This study aims to determine the attitudes of students in physics learning at the State High School in Batanghari Regency. The type of research used is quantitative which uses a research design survey that is strengthened by the results of interviews to support the results of quantitative data. This study involved 926 students of the Batanghari State High School. The data used by researchers in the form of a questionnaire/questionnaire consisting of 54 item statements using a Likert scale 5. Quantitative data analysis using descriptive statistics. The results of this study the researchers get the results of Good and Good Enough with the following details: The Social Implications of Physics have a Good result, amounting to 51.3\%. Attitudes in Physics Investigation have a sufficient result of 44.3\%, Enjoyment Learning Physics has Enough results of 55.5\%, Career Interest in Physics has Enough result of 45\%. This is due to the attitude that is sufficient on the indicator. The adequate attitude of students is a balanced attitude in learning Physics Subjects because subjects are difficult to understand.
\end{abstract}

Keywords: Attitudes; Social Implications; Investigation; Fun Learning; Career Interest in Physics

\section{INTRODUCTION}

Education is an activity that is very important for humans, with the existence of human education, can change behavior and knowledge for the better. Education is a process for acquiring and instilling skills carried out by students (Wood, 2011). Education itself has a goal to develop the potential contained in students, so they can think critically and creatively (Sisdiknas, 2003). In education in Indonesia itself, there are several levels, one of them is the High School level. High school is the level of education that must be taken before proceeding to the next stage of education to a higher level. In the level of high school education, studying various sciences one of the sciences studied is the subject matter of Physics. Physics Subjects is one of the sciences that develops from observing natural phenomena and interactions that occur within them (Asih, 2017). Besides Physics Subjects is a science that integrates with the behavior and symptoms of natural phenomena that are associated with current or current phenomena (Giancoli, 2014).

Subjects in Physics can be categorized as subjects that are less preferred by students. Students consider Physics Subjects to be a difficult subject during school and even more 
difficult when they reach college (Guido, 2013). This is because Physics Subjects are not only reliable in mathematics, but must be reliable in logic too. Physics lessons require strong logic and some basic knowledge of mathematics, based on content analysis and synthesis (Guzel, 2004). In the learning process, especially in Physics Subjects, the attitude of students is very important, because a good attitude will affect what is desired. The attitude that takes place during the learning process is very important in directing human behavior (Rich, 2011). Because, students who have this view will have different attitudes, with students who have more positive views during the learning process. The positive attitude of students in the learning process can affect or improve the learning outcomes of these students, and vice versa (Arsaythamby Veloo, 2015). Therefore, for students who have a positive attitude in learning will influence or improve the learning outcomes of these students.

That attitude comes from within the learner himself, namely the feeling of an object that is shown in feelings of like or dislike. This is consistent with (Nursa'adah, 2016) that attitudes are behavior or actions due to someone's reaction to other people or certain objects. Students who do not like Physics Subjects can be seen from their attitudes and learning outcomes towards Physics Subjects. Attitudes, both negative and positive in learning Physics Subjects, greatly affect learning outcomes in Physics and Science subjects, which is known that students behave negatively towards learning Physics Subjects will make learning now or in the future more difficult (Erdemir, 2009). Lack of positive attitudes that students have, towards Physics Subject lessons resulting in various problems. Students who have a negative attitude towards Physics Subjects will reduce their confidence level and make poor performance results due to lack of information seeking to solve Physics Subject problems (Olasimbo, 2012). If students have a negative attitude towards Physics Subjects, they will also be negative towards Physics Subject teachers (Guido, 2013). The students' positive attitude towards the eyes of Physics Subjects will be integrated with the Social Implications of Physics Subjects, scientific attitudes, learning pleasure in Physics Subjects, interest in increasing time to study Physics Subjects, and interested in a career in Physics Subjects.

The social implications of Physics
Subjects show how the effects or effects of Physics Subjects on social life. This can be in the form of attitudes towards social benefits and issues of progress and scientific research (Welch, 2010). The social implications of Physics Subjects themselves have benefits for each student because they will form independence and cooperation in the learning process. A concept that understands someone as an individual who is independent, independent and independent (Kuukkanen, 2012). For example in a discussion group or practicum a material, students are required to work together, get to know each other's personal learners and regulate the equal distribution of work for each individual, both in terms of ability or expertise, implement it independently and account for the results. The form of independence of students can also be seen from the execution of assignments or homework given by the teacher as well as how students add insight through enrichment and other sources (internet).

The attitude towards investigations in Physics Subjects contains the perceptions of students about the way or action in solving problems or problems in the Eye of Physics. In studying Physics Subjects, students usually conduct investigations, both in class and in the lab. Although it covers traditional science processes, the inquiry also refers to the incorporation of these processes with scientific knowledge and reasoning and critical thinking (Lederman, et al, 2013). Students develop confidence during school that in order to get conclusions, step by step is needed which must be followed in a scientific method, this is how scientists produce new knowledge (Moeed, 2013). Forms of Physics Subject investigation in class can be seen from the steps of how students answer a question, namely by observing an illustrated picture of an event, collecting and classifying known data, interpreting and analyzing it using an appropriate formula for problem solving. When in the laboratory, the study of Physics Subjects by students can be seen from how students obtain experimental data, namely by observing and deciding which tools need to be used, making hypotheses, taking or collecting data based on appropriate procedures to prove hypotheses, measure objects, analyze data the experiment then concludes the results and compares the data with the theory.

The pleasure that students have is because these students have a positive attitude 
when the learning process takes place. The pleasure of these students when learning will have a more intensive character when learning (Manasi, 2015). If students have a happy feeling when studying Physics Subjects, it can affect the learning outcomes of their Physical Subjects. Learning outcomes of Physics Subjects are well influenced by the enjoyment of learner's science, and pleasure provides a predictive effect of value in science learning (Ainley, 2011). Students who love learning Physics Subjects will have high curiosity, towards those subjects rather than other lessons. This high curiosity is influenced by several factors, one of which is a comfortable classroom. Comfortable classrooms can develop students' skills and enhance the learning pleasure of Physics Subjects (Rawatee Maharaj-Sharma, 2017).

The attitude of learners to learning Physics Subjects refers to feelings of excitement or attraction of students in learning Physics Subjects (Esther Agunbiade, 2017). The learning outcomes of Physics Subjects and the attitude of students themselves will influence students to be interested in a career in the field of Physics Subjects. If students behave negatively towards Physics Subjects, the Students have no interest in a career in Physics Subjects. Positive attitudes and interests in Physics Subjects will lead to future careers in the field of Physics Subjects will increase (Welch, 2010). Because of the difficulties in the subject matter of Physics Subjects, it causes students not to be interested in a career in the field of Physics Subjects. Many students who have Physics Subjects are boring and for a career in Physics, Subjects is a hard job (Arsaythamby Veloo, 2015). One that affects students to get a career in the field of Physics is the interest or interest of the students themselves. Therefore, to improve students in a career in the field of Physics Subjects need to pay attention to their interests, which interest greatly affects the achievement of career and personal life (Arslan, 2015).

Attitudes are very important in the process of learning. Because if students have a negative attitude towards Physics Subjects, they will also be negative towards Physics Subject teachers (Guido, 2013). Therefore, the teacher must know how the attitudes of students that occur during the learning process because by knowing the attitudes of students, the teacher can improve the design of learning in the classroom, in accordance with the abilities that students have. One of the attitudes of students, which needs to be considered by a teacher is a scientific attitude. Trumper (2006) scientific attitudes greatly influence the learning process that involves the attitude of students. Students who have a scientific attitude that will be high will help the process of learning science and Physics Subjects get better. This is because scientific attitudes can form students to think creatively and critically.

The purpose of this study was to find out the attitudes of students towards learning Physics Subjects in high schools precisely in SMA Batanghari district. The attitude indicators include the Social Implications of Physics Subjects, Attitudes towards Investigations in Physics Subjects, pleasure in learning Physics Subjects, and career interest in Physics Subjects. The findings of this study can contribute to improving students' attitudes towards learning Physics Subjects.

\section{METHOD}

The research design used by researchers is quantitative research that uses the research design is survey research. Survey research is a procedure in quantitative research where researchers administer surveys to a sample or to the entire population used to describe population attitudes, opinions, behaviors, or special characteristics (Creswell, 2012: 752). The design of this study was applied because it was in accordance with the objectives of the study, where the aim was to find out the Attitudes of High School Students to the Subjects of Physics. The sample that the researchers used came from 926 Students consisting of 5 high schools located in Batanghari Regency. With the details of each school: 1. SMAN 1 Batanghari as many as 281 Students with male participants 119 people and female students as many as 162 people, 2. SMAN 5 Batanghari as many as 126 students with male students 58 people and Female students as many as 68 people, 3. SMAN 6 Batanghari as many as 225 students with male students 87 people and female students 138 people, 4. SMAN 8 Batanghari as many as 141 students with male students as many as 32 people and Female students as many as 109 people and SMAN 10 Batanghari as many as 153 students with male students as many as 57 people and female students as many as 96 people. In this study, the researchers used purposive sampling. Purposive sampling is a sampling technique based on the criteria of the 
researcher (Kerlinger, 2014). The criteria of the researchers are Accredited Schools, with an age limit of 15 to 17 years.

This study uses a questionnaire instrument, the questionnaire was adopted from the research of Rio Darmawangsa (2018) which has 54 valid statements with Cronbach Alpha values of 0.9 . The statement has 7 indicators, in this study, researchers used 4 indicators using a 5 (five) Likert scale (for positive statements Strongly Disagree having a score of 1, Disagree having a score of 2, Neutral having a score of 3, Agree having a score of 4 and Very Agree 5. For negative statements Strongly Disagree has a score of 5, Disagree has a score of 4, Neutral has a score of 3, Agree has a score of 2 and Strongly Agree has a score of 1). Interviews use semistructured interview types.

Data analysis, in this study using quantitative analysis data using the SPSS program to look for descriptive statistics, descriptive statistics are a description or presentation of large amounts of data, in this case in the form of summary frequencies, for example mode, mean, median, minimum, maximum and standard deviation (Cohen, Manion \& Morrison, 2007). Followed by interviews intended to strengthen the results of quantitative data. The steps in the interview can be seen as follows: (1) to calculate frequencies such as ideas, themes, pieces of data and words. (2) pay attention to patterns and themes. (3) try to make good data, using intuition to reach conclusions. (4) do groups arrange items into categories, types, behaviors, and classifications? (5) create a metaphor that uses figurative and connotative language rather than literal and denotative language, animates data, thereby reducing data, making patterns, harmonizing data, connecting data with theory. (6) separating variables to decipher, differentiate and 'dismantle' ideas, namely moving from drive to integration and blurring data. (7) surrender specifically into the general, carrying a large number of variables under a small number (often) of unobserved hypothetical variables. (8) identify and record relationships between variables. (9) find intervening variables: look for other variables that seem to 'block' calculations for what is expected to be a strong relationship between variables. (10) build a logical chain of evidence: record causality and make conclusions. (11) Creating conceptual/theoretical coherence: moves from a metaphor to construct a theory to explain phenomena (Cohen, Manion \& Morrison, 2007).

\section{RESULTS AND DISCUSS}

\section{Results}

\section{Social Implications of Physics Subjects}

On the social implications of High School Students on Physics Subjects we can see the results from questionnaires that have been distributed, with results such as table 1:

Table 1 Social Implications Indicators of Physics Subjects of Students in Batanghari High School

\begin{tabular}{|c|c|c|c|c|c|c|c|c|c|}
\hline \multicolumn{3}{|c|}{ Classification } & \multirow{2}{*}{$\begin{array}{l}\text { Standard } \\
\text { deviation }\end{array}$} & \multirow[t]{2}{*}{ Mean } & \multirow[t]{2}{*}{ Modus } & \multirow[t]{2}{*}{ Median } & \multirow[t]{2}{*}{ Min } & \multirow[t]{2}{*}{ Max } & \multirow[t]{2}{*}{$\%$} \\
\hline Interval & Attitude & Total & & & & & & & \\
\hline $5-8$ & $\begin{array}{l}\text { Not Very } \\
\text { Good }\end{array}$ & 1 & & & & & & & 0.3 \\
\hline $9-12$ & Not Good & 19 & & & & & & & 2.3 \\
\hline $13-16$ & Enough & 218 & 2.85 & 18.34 & 17 & 18 & 8 & 25 & 23.1 \\
\hline $17-20$ & Good & 475 & & & & & & & 51.3 \\
\hline $21-25$ & Very Good & 213 & & & & & & & 23 \\
\hline TOTAL & & 926 & & & & & & & 100 \\
\hline
\end{tabular}

In table 1, it was obtained from 926 respondents who had filled out the questionnaire and were processed using the SPSS program. Then the results are as follows: standard deviation 2.85 , mean 18.34 , mode 17 , median 18 , $\min 8$, and $\max 25$. A total of $51.3 \%$ of (475 of 926) Students are in a good category and
$23.1 \%$ of (213 of 926) Students categorized very good, with a maximum score of the overall statement is 25 . This shows that most students recognize the implications of Physics Subjects in their social life. A total of $23.1 \%$ of (218 out of 926) sufficiently categorized students means that students are still confused about the role of 
Physics Subjects in technological progress. Whereas $2.3 \%$ of (19 out of 926) students are categorized as not good, this shows the students do not understand the good implications for their social life.

\section{Attitudes in Investigating Physics Subjects}

The results of the questionnaire that have been disseminated for indicators Attitudes in the investigation of physics subjects for high school students can be seen in table 2 below:

Table 2 Indicators of Attitudes in Investigation of Physics Subjects of Students in Batanghari High School

\begin{tabular}{|c|c|c|c|c|c|c|c|c|c|}
\hline \multicolumn{3}{|c|}{ Classification } & \multirow{2}{*}{$\begin{array}{l}\text { Standard } \\
\text { Deviation }\end{array}$} & \multirow[t]{2}{*}{ Mean } & \multirow[t]{2}{*}{ Modus } & \multirow[t]{2}{*}{ Median } & \multirow[t]{2}{*}{ Min } & \multirow[t]{2}{*}{ Max } & \multirow[t]{2}{*}{$\%$} \\
\hline Interval & Attitude & Total & & & & & & & \\
\hline $9-16$ & $\begin{array}{l}\text { Not Very } \\
\text { Good }\end{array}$ & 0 & & & & & & & 0 \\
\hline $17-24$ & Not Good & 31 & & & & & & & 3.3 \\
\hline $25-32$ & Enough & 410 & 4.38 & 30.98 & 31 & 31 & 17 & 43 & 44.3 \\
\hline $33-40$ & Good & 410 & & & & & & & 44.3 \\
\hline $41-48$ & Very Good & 75 & & & & & & & 8.1 \\
\hline & TAL & 926 & & & & & & & 100 \\
\hline
\end{tabular}

In table 2, it was obtained from 926 respondents who had filled out the questionnaire and were processed using the SPSS program. Then the results are as follows: standard deviation of 4.38 , mean 30.98 , mode 31 , median 31 , min 17 and max 43 . As many as $44.3 \%$ of (410 of 926) Learners have the Enough category. But for students who are categorized as good overall based on acquisition data analysis, which is as much as $44.3 \%$ of (410 of 926) Students, and $8.1 \%$ of (75 of 926) Students are very good categorized. Whereas the attitude of the Learners to the Poorly categorized Physics Subject is 3.3\% of (31 of 926) Students. The maximum score achieved is 43 and the minimum score is 17 . This explains that generally, the students have behaved well on the attitude indicators in the investigation of the usual Physics Subjects. But some students also do not like to solve problems themselves but ask experts or other alternatives. This also means the attitude of the students in Physics Subject investigations is classified as standard and ordinary and not too influential on the development of learning.

\section{Fun in Learning Physics Subjects}

The results of the questionnaire that has been processed about learning pleasure Physics Subjects can be seen in table 3:

Table 3 Indicators of the attitude of students' enjoyment of Physics Subjects in Batanghari High School

\begin{tabular}{|c|c|c|c|c|c|c|c|c|c|}
\hline \multicolumn{3}{|c|}{ Classification } & \multirow{2}{*}{$\begin{array}{l}\text { Standard } \\
\text { Deviation }\end{array}$} & \multirow[t]{2}{*}{ Mean } & \multirow[t]{2}{*}{ Modus } & \multirow[t]{2}{*}{ Median } & \multirow[t]{2}{*}{ Min } & \multirow[t]{2}{*}{ Max } & \multirow[t]{2}{*}{$\%$} \\
\hline Interval & Attitude & Total & & & & & & & \\
\hline $10-18$ & $\begin{array}{l}\text { Not Very } \\
\text { Good }\end{array}$ & 25 & & & & & & & 2.3 \\
\hline $19-27$ & Not Good & 134 & & & & & & & 16.8 \\
\hline $28-36$ & Enough & 510 & 6.47 & 32.3 & 31 & 32 & 10 & 50 & 55.5 \\
\hline $37-45$ & Good & 232 & & & & & & & 22.7 \\
\hline $46-54$ & Very Good & 25 & & & & & & & 2.7 \\
\hline & TAL & 926 & & & & & & & 100 \\
\hline
\end{tabular}

In table 3, it was obtained from 926 respondents who had filled out the questionnaire and were processed using the SPSS program. Then the results are as follows: Mean 32.3, Mode 31, Median 32, Minimum Score 10, Maximum Score 50 and Standard Deviation of 6.47. The more dominant respondents chose enough as much as $55.5 \%$ of (510 from 926) Students, then good at $22.7 \%$ of (232 from 926) Students and very good at $2.7 \%$ of (25 out of 926) Students, for non-good categories of $16.8 \%$ of (134 of 926) Students and Very Bad at 2.3\% of (25 out of 926) Students. 


\section{Career Interest in Physics Subjects}

The results of the questionnaire that has been processed regarding indicators about
Career Interest in Physics Subjects can be seen

in table 4 :

Table 4 Attitude Indicators of students' interest in a career in Physics Subjects at Batanghari Public High School

\begin{tabular}{|c|c|c|c|c|c|c|c|c|c|}
\hline \multicolumn{3}{|c|}{ Classification } & \multirow{2}{*}{$\begin{array}{l}\text { Standard } \\
\text { Deviation }\end{array}$} & \multirow[t]{2}{*}{ Mean } & \multirow[t]{2}{*}{ Modus } & \multirow[t]{2}{*}{ Median } & \multirow[t]{2}{*}{ Min } & \multirow[t]{2}{*}{ Max } & \multirow[t]{2}{*}{$\%$} \\
\hline Interval & Attitude & Total & & & & & & & \\
\hline $10-17$ & $\begin{array}{l}\text { Not Very } \\
\text { Good }\end{array}$ & 11 & & & & & & & 4 \\
\hline $18-25$ & Not Good & 146 & & & & & & & 26 \\
\hline $26-33$ & Enough & 604 & 5.69 & 32.06 & 32 & 30 & 10 & 55 & 45 \\
\hline $34-41$ & Good & 141 & & & & & & & 16 \\
\hline $42-50$ & Very Good & 24 & & & & & & & 9 \\
\hline & TAL & 926 & & & & & & & 100 \\
\hline
\end{tabular}

In table 4 , it was found that out of 926 respondents who came from the senior high school level of education had completed the questionnaire and were processed using the SPSS program. Then the results are as follows: Mean 32.06, Mode 32, Median 30, Minimum Score 10, Maximum Score 50 and Standard Deviation of 5.69. The dominant respondents chose the Enough category of $45 \%$ of (604 out of 926) Students, then Not Good 26\% of (146 of 926) Students, Good 16\% of (141 of 926) Students, Very Poor 4\% of ( 11 out of 9260 Learners and the least were Very Good at $9 \%$ of (24 of 926) Students.

\section{Discussion}

That student attitudes can be seen from feeling happy, unhappy, like or dislike, motivated or unmotivated. Attitude is a term that reflects pleasure, displeasure or an ordinary feeling (neutral) of a person towards something (Oba, 2014). Renewal in this study is a review of the attitudes seen from the indicators used, namely the social implications of the eyes of the physics instructor, Attitudes in the investigation of physics subjects, Fun in learning subjects, Interest in a career in the field of physics at SMAN Batanghari.

\section{Social Implications of Physics Subjects}

The results of the questionnaire analysis in table 1 with indicators of social implications from Physics Subjects in Batanghari District High School showed that the dominant students were in a good category. This research reinforces the results of Veloo's research, namely the concepts and principles of Physics Subjects are widely applied to life and contribute a lot in the development of social life (Arsaythamby Veloo, 2015). Based on the results of the interview, it shows that even though Physics Subjects are difficult for students, they must learn abstract formulas and concepts. The results of the interview stated that "Every time there is a problem, the formula is definitely different in form, there are many constants or numbers that must be memorized. And most of the theories have to be imagined first when studying, so it's hard if you don't know the picture. " However, students know that the Physics Subject concepts and formulas have been applied and bring many benefits in daily life. Furthermore, from interviews also obtained such as "benefits in life such as in a vehicle or electric technology, many use the concept of Physics Subjects". (Guido, 2015) Students who can appreciate the role of Physics Subjects in everyday life are only students who excel in high school physics subjects, are talented in science and are very good at mathematics.

\section{Attitudes in Investigating Physics Subjects}

The results of the questionnaire data analysis in table 2 with attitude indicators in the investigation of Physics Subjects in Batanghari District High School showed that the dominant students were in a good category. Based on the results of the interview stating that "wellcategorized pesetas do have an active attitude in doing when finding things that are contrary to the experimental results, students respond critically, have high curiosity and never give 
up". However, by conducting experiments, Physics Subject lessons are not boring. I also know the application of Physics Subject laws. "If you have trouble finding answers or certain things during the experiment, you would rather find your own answers or ask friends". If I still can, I prefer to find out myself and read in my book. But if you don't know, I just asked the teacher or friend.

The results of interviews conducted, it was found that students like to conduct experiments, which indicates that these students like to think critically, find interesting new things from Physics Subjects through the investigation they did. Physics subject matter is based on concepts so that in learning abstract things there will be obstacles for students and teachers (Civelek, 2014). By conducting experiments, abstract Physics subject matter becomes easier to understand and attract students. Students who are still strong to find answers to difficult problems in the investigation show students' confidence in their abilities. Students' confidence in their ability to study natural sciences and mathematics largely determines their involvement in investigative activities (Stefan and Ciomos, 2010). The attitude of students who like to ask after trying to find a solution or answer shows that the students' curiosity is very large towards the investigation that they do. Forms of appreciation and support for a scientific inquiry from students show that they value the scientific way of gathering evidence, thinking creatively, thinking rationally, responding to, and communicating, conclusions, because they face life-related situations related to science (Rodger Bybee et. Al. , 2009).

\section{Fun in Learning Physics Subjects}

Based on the analysis of questionnaire data processing in Batanghari District High School on indicators of pleasure in learning Physics Subjects addressing the most dominant attitude is a fairly categorized attitude with a percentage of $55.5 \%$. From the results of these data, it can be said that the attitude of pleasure Learners in learning Physics Subjects is sufficient or the average is positive. The results of interviews with students who are categorized as sufficiently known that like to study Physics Subjects for various reasons, for example, because Physics Subject matter has to do with daily life and because learning Physics Subjects is very pleasant. "Do you enjoy learning Physics
Subjects?" I like it because learning Physics Subjects has many advantages in everyday life and comfortable classrooms, making me better understand Physics Subjects, so I love learning Physics Subjects.

A good attitude towards pleasure in learning Physics Subjects is one of the important elements in learning Physics Subjects. Ainley (2011) states that good Physics Subject learning outcomes are influenced by learners' scientific enjoyment and pleasure which provides predictive effects in science learning. Incorrect learners' positive attitudes in the indicators of learning pleasure Physics Subjects are caused by classrooms. Comfortable classrooms can develop students' skills and enhance the learning pleasure of Physics Subjects (Rawatee MaharajSharma 2017). The happy attitude in learning Physics Subjects that Students have will make Students enjoy the learning process of Physics Subjects in the classroom so that Students succeed in learning Physics Subjects. Experience positive emotions such as the relationship of pleasure and pleasure with successful learning and self-perceptions about improving well-being (Lucardie, 2014).

\section{Career Interest in Physics Subjects}

Can be seen from the results of questionnaire data processing in Batanghari District High School, on the indicators of interest in a career in the field of Physics Subjects, the most dominant attitude of the Learners is the sufficient category of $46 \%$. The results of these data show the average Student has a positive attitude in a career in the field of Physics Subjects. Based on the results of interviews with students who are categorized as sufficient attitude, it is known that "when they are adults want to work in the field of Physics Subjects". However, they are interested in a career in Physics Subjects.

"I want to have a career in Physics Subjects, but not to become a teacher, because being a teacher is a hard job".

Interest and interest are the main keys to increasing student participation in a career in the field of physics subjects. To be able to improve students in a career in the field of Physics Subjects need to pay attention to their interests which interest greatly influences the achievement of career and personal life (Arslan, 2015). The interest in science possessed by students at the secondary school level affects careers related to science in the future (Juan, 
2016). In addition to interest, have a positive attitude of students who in learning Physics Subjects also affect the career of students in the field of Physics. Having a positive attitude and interest in Physics Subjects can lead to a future career interest in the field of Physics Subjects will increase (Welch, 2010). Career interest in Physics Subjects is one of the good capital to improve learning outcomes in Physics Subjects. A career in Physics causes students to be interested in learning Physics Subjects that will affect achievement and learning outcomes (Rodger Bybee, 2009). Students who want to pursue a career in the field of Physics Subjects will broaden their horizons and curiosity towards Physics Subjects.

From the results obtained by researchers based on the questionnaires that have been disseminated, there is a very dominant obstacle, namely Career Interest in Physics Subjects which has a very high percentage of 926 Middle School students in Batanghari regency, which is $35 \%$. From the results the researchers found in the field, why is the interest in a career in the field of Physics Subjects very large, it is due to the lack of interest possessed by each student to deepen the learning of Physics Subjects themselves. Because for a career in the field of Physics Subjects must also pay attention to the interest of the Learners in the lesson itself because interest greatly influences the career achievements and personal lives of Students (Arslan, 2015). Then the obstacle that has a high percentage level of 926 students is the fun in learning physics subjects, which is $19.1 \%$. From the results that the researchers have found, namely why the learning pleasure in Physics Subjects is quite high, because the learning and learning process is not good and also the lack of support from facilities and infrastructure which in this case is the condition of the classroom that is quite inadequate, resulting in a lack of pleasure Students learn specifically, in the subject matter of Physics. Because, comfortable and feasible classrooms can develop and foster the skills of learners and pleasure Students in learning, especially in Physics Subjects (Rawate Maharaj-Sharma, 2017).

Problems faced in improving attitudes

Table 5 Constraints found in Batanghari Regency High School Middle School students

\begin{tabular}{lc}
\hline \multicolumn{1}{c}{ Statement } & Learners (n=926) \\
\hline Social Implications of Physics Subjects & $20(2.6 \%)$ \\
Attitudes in Physics Subject Investigation & $31(3.3 \%)$ \\
Fun in Learning Physics Subjects & $159(19.1 \%)$ \\
Career Interest in Physics Subjects & $157(30 \%)$ \\
\hline
\end{tabular}

From the results that have been obtained from the respondents who have filled out the questionnaire distributed by the researchers, the researchers found that there were 4 obstacles that were found by the students towards their attitudes toward Physics Subject learning (Table 4.5): Social Implications of Physics Subjects (2.6\%), Attitudes in Physics Subject Investigation (3.3\%), Physics Subject Learning Fun (19.1\%), Career Interest in Physics Subjects $(35 \%)$.

In the results obtained from the respondents, the researchers also found other obstacles, namely the social implications of Physics Subjects, there were 20 respondents or $2.6 \%$ of 926 students categorized as bad attitudes. The obstacles faced by students are that they think that Physics Subjects are something complicated and abstract so it is difficult to find a solution to the problem. Students are often difficult to interpret the symbol of events in the equation (Kabil, 2015). Next is the attitude in the investigation of Physics Subjects, $3.3 \%$ of Students or a number of 31 Students in the category of bad attitude. Constraints faced by students in the form of thinking patterns Students who prefer to get answers instantly in Physics Subjects and do not like structured activities because it is 
complicated and unpleasant. The students' assumption that Physics Subjects are very abstract and very difficult is one of the problems (Pehlivan and Koseoglu, 2011). Students cannot think critically because they are lazy and lack curiosity. If they are happy with Physics Subjects, they will help the students themselves. Students who are very interested in increasing their study time, especially in learning Physics Subjects, will improve achievement, learning outcomes and interest in a career in the field of Physics (Rodger Bybee, 2009). Therefore, because of the lack of interest of students in a career in the field of Physics Subjects and the lack of fun in learning Physics Subjects which causes Students not to increase the time to study Physical Subjects.

\section{CONCLUSIONS AND SUGGESTIONS}

From the results of the analysis that has been done, it was found that the attitudes of students in Batanghari high school on indicators of attitudes toward Physics Subject research, fun in learning Physics Subjects and career interest in Physics Subjects Students are quite good at being balanced with attitude Students on the indicator of adoption of scientific attitudes that students behave well. This is because a sufficient attitude on the three indicators will influence the social implications of the Physics Subject. The adequate attitude of students is a balanced attitude in learning Physics Subjects because subjects are difficult to understand.

Suggestions from researchers, so that schools in Batanghari High School can improve the attitudes of students or students, in order to improve in terms of the affective domain of students.

\section{REFERENCES}

Ainley, M. A. (2011). A Cultural Perspective on the Structure of Student Interest in Science. International Journal of Science Education, 51-71.

Arsaythamby Veloo, R. N. (2015). Attitude towards Physics and Additional Mathematics Achievement towards Physics Achievement. International Education Studies, 35-43.

Arslan, N. I. (2015). High school students' educational and career interest (sciencetechnology- mathematics) and career adaptabilities. Australian Council for Educational Research, 166-172.

Asih, D, A, P. (2017). Pengaruh Pengguna Fasilitas Belajar di Lingkungan Alam Sekitar Terhadap Keterampilan Proses Sains. Jurnal Formatif, 7(1): 13-21.

Civelek, Turhan, Erdem Ucar \& Hakan Ustunel. (2014).Effects of a Haptic Augmented Simulation on K-12 Students'Achievement and their Attitudes towards Physics, Eurasia Journal of Mathematics, Science \& Technology Education, vol 10(6), Hal. 565-574.

Cohen, L. M. (2007). Research Methods in Education. New York: Routledge.

Creswell, J. W. (2012). Research Design Pendekatan Kualitatif, Kuantitaif dan Mixed Cetakan ke-2. Yogyakarta: Pusaka Belajar.

Darmawangsa, R. (2018). Pengembangan instrument sikap siswa sekolah menengah atas terhadap mata pelajaran fisika. JPF: Jurnal Pendidikan Fisika, 6(1), 107-114.

Depdiknas. (2003). Undang-undang RI No.20 tahun 2003. Tentang sistem pendidikan nasional.

Erdemir, N. (2009). Determining students' attitude towards physics through problem-solving strategy. Asia-Pacific Forum on Science Learning and Teaching, 1-19.

Esther Agunbiade, K. N. (2017). An Exploratory Study of the Relationship between Learners' Attitudes Towards Learning Science and Characteristics of an Afterschool Science Club. African Journal of Research in Mathematics, Science and Technology Education, 271-281.

Guido, R. M. (2013). Attitude and Motivation towards Learning Physics. International Journal of Engineering Research \& Technology, 2087-2094.

Giancoli, D. C. (2014). Mata Pelajaran Fisika : Prinsip dan Aplikasi Edisi ke 7Jilid 1., Jakarta: Erlangga.

Guzel, Hatice. (2004). The Relationship Between Students' Success in Physics 
Lessons and Their Attitude Towards Mathematics. Turkish Science Education,

Juan, A. R. (2016). Does it matter whether students enjoy learning science? Exploring student attitudes towards science in South Africa. Human Sciences Reseach Council, 1-6.

Kabil, Onur. (2015). Philosophy In Physics Education. Procedia-Social and Behavioral Sciences 197. Doi:10.1016/7.sbspro.2015.07.057 hal 675-679.

Kaya, H. \&. (2011). Attitude towards Physics Lessons and Physical Experiments of the High School Students. European journal of physics education, 23-31.

Kerlinger, F. N. (2014). Foundations of behavioral research. Yogyakarta: Gadjah Mada University Press.

Kuukkanen, J.-M. (2012). Autonomy and Objectivity of Science. International Studies in the Philosophy of Science, 309-334.

Lederman, N.G., Lederman, J.S., \& Antink, A. (2013). Nature of science and scientific inquiry as contexts for the learning of science and achievement of scientific literacy, International Journal of Education in Mathematics, Science and Technology, 1(3), 138-147.

Lucardie, D. (2014). The impact of fun and enjoyment on an adult's learning. Procedia - Social and Behavioral Sciences, 439 - 446.

Manasi, L. (2015). Enjoyment of learning in upper secondary education. An exploratory research. Procedia - Social and Behavioral Sciences, 639-646.

Moeed, Azra. (2013). Science investigation that best supports student learning: Teachers' understanding of science investigation. International Journal of Environmental \& Science Education. DOI: 10.12973/ijese.2013.218a. 2013.8.537559 .

Nursa'adah, F, P \& Rosa, N, M. (2016). Analisis kemampuan Berpikir Kreatif Kimia Ditinjau dari Adversity Quotient, Sikap
Ilmiah dan Minat Belajar. Jurnal Formatif, 6(3): 197-206.

Olasimbo, O. a. (2012). Attitudes of Students towards the Study of Physics in College of Education Ikere Ekiti, Ekiti State, Nigeria. American International Journal of Contemporary Research, 86-89.

Oba, Fatoba, J \& Lawrence, Aladejana, A. (2014). Effects Of Gender On Student' Attitude To Physics In Secondary Schools In Oyo State, Nigeria. 10(7), 399-404.

Pehlivan, Hulya and Pinar Koseoglu. 2011. The reliability and validity study of the attitude scale for physics course. Procedia Social and Behavioral Sciences.

doi:10.1016/j.sbspro.2011.04.296 hal 3338-3341

Rawatee Maharaj-Sharma, A. S. (2017). Using Ict In Secondary School Science Teaching - What Students And Teachers In Trinidad And Tobago Say. European Journal of Education Studies, 197-211.

Rodger Bybee, B. M. (2009). PISA 2006: An Assessment of Scientific Literacy. Journal Of Research In Science Teaching, 865-883.

Stefan, M., dan Florestina ciomos. (2010). The $8^{\text {th }}$ and $9^{\text {th }}$ Grades Students' Attitude Towards Teaching and Learning Physics. Acta Didactica Napocensia, Vol. 3, No. 3: 7-14.

Trumper, Ricardo. 2006. Factors Affecting Junior High School Students' Interest in Physics. Journal of Science Education and Technology, Vol. 15, No. 1, p.47-58.

Welch, A. G. (2010). Using the TOSRA to Assess High School Students' Attitudes toward Science after Competing In the FIRST Robotics Competition: An Exploratory Stud. Eurasia Journal of Mathematics, Science \& Technology Education, 187-197.

Wood, K. (2011). Education is Basic. New York: Taylor \& Francis Group. 